\title{
The place of composing in curriculum design
}

One aspect of school music education in Britain that often draws comment from those based in other jurisdictions is that of the place and role of composing in the statutory curriculum for all children and young people in schools. It may well be the case that much of this is due to the work of two former editors of the British Journal for Music Education, John Paynter and Keith Swanwick, who both published significant works in this field many years ago, including, but not limited to, nearly 50 years ago with John Paynter and Peter Aston's Sound and Silence (Paynter \& Aston, 1970) and 40 years ago with Keith Swanwick's A Basis for Music Education (Swanwick, 1979). There have been many publications in music education since those, but it is significant that the impact on pedagogies of music education in Britain have been significantly impacted by their contributions. It is worth pausing to consider what this means for teaching and learning in school music today, and what the international community might learn from experiences in UK schools. Music education, as we have observed before, is a broad endeavour, and composing, listening, appraising, analysing and performing all figure to various degrees in it, in different parts of the world.

We do know, however, that in a number of jurisdictions the content of the music education curriculum is based on what might be termed primarily a performance modality. We also know that in some places music is an opt-in, with children and young people choosing to be involved in learning to play an instrument and/or singing. Clearly, different traditions have grown up in different places because local conditions have been suitable and appropriate to those circumstances. However, in a rapidly changing world, thinking about what might have been suitable last century, or the one before that, may be outmoded. It is here that we need to return to the work of Paynter and Swanwick. Fifty years ago is a long time, and for the current generation of new teachers now entering universities for their teacher preparation courses, will have been before they were born. So the shock that some of these new teachers have when encountering thinking about composing in this fashion needs placing in the context of a music education world 50 years ago, and the shocks that were felt then. Have we moved on much? That might depend on who you listen to!

So what has happened in the intervening time? Well, a huge amount. Technology has changed hugely, with the Minimoog synthesiser being a contemporary of the Paynter book 50 years ago. Nowadays more music creation and recording power is available on the phones in many pockets. But what does this mean for curriculum music in schools? We know that children and young people are very much involved with the consumption of music, but technology has also democratised music education, making the creation, production and distribution of new music far more accessible than the creators of the moog synthesiser could have imagined. However, as the saying goes, just because a young person creates their own song, it does not mean that somewhere else a viola dies! But what about the knowledge, skills and understanding needed to play that viola, or any orchestral instrument? Well, one of the strengths of composing pedagogies in the UK and elsewhere has been nurturing the creative responses of beginning instrumentalists. The notes that young musicians learn to play are not the exclusive province of the tutor books in which they are to be found; these are the common vernacular of diatonic music, and so encouraging learners to be creative with the notes they have learned to play has figured in instrumental music lessons for many years. 
This brings us back to composing. In the UK model, this does not need to involve pencil and paper, treble clefs and key signatures - although it might; it can be music composed directly into sounds. As Swanwick wrote in the book cited above:

Composition is the act of making a music object by assembling sound materials in an expressive way. There may or may not be experimentation with sounds as such... Whatever form it may take, the prime value of composition in music education is not that we may produce more composers, but in the insight that may be gained by relating to music in this particular and very direct manner. (Swanwick, 1979, p. 43)

This view of composing still holds true, at least for curriculum purposes in England. In these days of 'knowledge-rich' curricula, we must not lose sight of the 'particular and very direct manner' which composing affords young people as a normal and regular part of their music education, wherever in the world they happen to be learning, playing, performing and composing. Whatever and wherever, we know that the BJME will be there with interesting and thoughtprovoking research articles on all aspects of music education, and music in education.

This brings us to the articles in this latest edition of the journal. These are once again contributed from colleagues around the world, reminding us of the importance of music education globally both in and out of schools. We start with an exploration by Almudena Ocaña-Fernández and María Luisa Reyes-López of young children's sound worlds and the potential to link children's experiences of music from informal and non-formal spaces with their engagement with planned musical learning in educational settings. This article, set in a Spanish context, draws upon a range of evidence of engagement in music from a variety of contexts. The article that follows also links with the sociocultural perspectives of learning. Tine Grieg Viig's case study of a creative project facilitated by professional artists in a Norwegian primary school considers multiple aspects of this kind of work. The particular focus is on the mediating tools used in creative music practices; the notion of time and also the consideration of the role of the facilitator in mediating learning in different contexts are particularly interesting dimensions to consider within this study.

Moving to Ireland, our next article, from Carrie McCarthy, Joanne O'Flaherty and Jean Downey, explores the perceptions of students aged 16-18 in relation to the reasons they continue to study music. Their study probes the complex interrelated factors impacting these choices, also highlighting that the importance of practical, embodied musical experience is fundamentally important to the young people involved. Christine Carroll's article, "Illiterate" Musicians: An Historic Review of Provision for Student Popular Musicians in Australian Senior Secondary Classrooms', shines a spotlight on curriculum developments in New South Wales and the changing position and inclusion of popular music and musicians since post-World War II.

The final three articles in this edition all consider aspects of teacher development, and there are some interesting similarities and differences that cross levels of experience (pre-service and inservice), the age ranges taught, and the geographical locations around the world where these studies have taken place. Jihae Shin's study explores experienced Korean primary teachers' perceptions of their difficulties in music classes. It draws out some interesting points about teachers' own concerns relating to how they see themselves as musicians, something which is also considered in the final two articles in this edition. Shin also urges the need for relevant and ongoing professional development for teachers in order to retain and grow their services in the workforce. Dawn Joseph's article from Australia demonstrates the potentially positive impact of creating an enabling environment that nurtures teachers in happy and safe learning spaces. It explores pre-service generalist primary teachers' growth in confidence when there is a focus on improving health and well-being. The final article in this edition, by Clint Randles and Leonard Tan, provides a comparison between pre-service music education students in the United States and Singapore. It draws out some interesting similarities between the teachers from both countries, and also some 
key differences about the values teachers place on areas such as creative identity and the use of popular music within their work.

As we noted in the opening section, there are a lot of aspects to music education, and once again, the broad range and scope of these articles in the BJME are testament to this. We hope, wherever in the world you are reading this, these provide intellectual stimulation.

\section{Martin Fautley and Alison Daubney}

\section{References}

PAYNTER, J. \& ASTON, P. (1970). Sound and Silence. Cambridge: Cambridge University Press.

SWANWICK, K. (1979). A Basis for Music Education. Windsor: NFER-Nelson. 